Kalem Eğitim ve İnsan Bilimleri Dergisi 2017, 7(2), doi: 10.23863/kalem.2018.89

Makale Gönderim Tarihi:22.09.2016

Makale Kabûl Tarihi:16.02.2017

\title{
İlkokul Yöneticilerinin Sâhip Olması Gereken Hizmetkâr Liderlik Özelliklerine İlişkin Öğretmen Görüşleri
}

\author{
Yrd. Doç. Dr. Metin ÖZKAN* \\ Gaziantep Üniversitesi, Gaziantep Eğitim Fakültesi, Şahinbey / Gaziantep / Türkiye, \\ ozkan.metin@gmail.com, ORCID: 0000-0002-4891-9409

\section{Eser TEMİZ} \\ Gaziantep Üniversitesi, Eğitim Bilimleri Enstitüsü, Şahinbey / Gaziantep / Türkiye, \\ esser_temiz@hotmail.com, ORCID: 0000-0002-6684-0702
}

\section{$\ddot{\mathbf{O z}}$}

$\mathrm{Bu}$ araştırmanın amacı, öğretmenlerin görüşlerine göre ilkokul yöneticilerinin sâhip olması gereken hizmetkâr liderlik özelliklerini belirlemektir. Araştırma nitel araştırma yaklaşımıyla desenlenmiştir. Araştırılan değişkenin doğasına uygunluğu nedeniyle, araştırmada olgu bilim deseni kullanılmışırı. Araştırmacılar tarafından hazırlanan altı açık uçlu soru ve bu sorulara bağlı alt sorulardan oluşan yarı yapılandırılmış görüşme formu veri toplama aracı olarak kullanılmıştır. Amaçlı örnekleme yöntemlerinden kartopu örnekleme yöntemi ile katılımcılar belirlenmiştir. Bu bağlamda, 2015-2016 eğitim öğretim yılında Şanlıurfa ili merkez ilçelerdeki ilkokullarda çeşitli projelerde görev almış 10 öğretmenle görüşmeler gerçekleştirilmiştir. Katılımcılara okul müdürlerinin hizmetkâr liderlik özelliklerini belirlemeye yönelik 5 boyutla

* Sorumlu Yazar. Tel: +90 5058966088

(C) 2017 Kalem Eğitim ve Sağlık Hizmetleri Vakfı. Bütün Hakları Saklıdır. ～ISSN: 2146-5606 
(empati, özgecil davranışlar, alçakgönüllülük, adâlet, dürüstlük) ilgili sorular yöneltilmiştir. Görüşme sonunda elde edilen veriler, betimsel analiz yöntemiyle, belirtilen beş temada sınıflandırılmıştır. Araştırmada, ilkokul öğretmenlerinin görüşlerine ilişkin olarak; ilkokul yöneticilerinin etkili iletişim becerisine sâhip olma, meslekî bilgi ve beceriye sâhip olma, işbirlikçi olma, âdil olma, özeleştiri yapma, problem çözme becerisine sâhip olma ve güven verme gibi birtakım özelliklere sâhip olması gerektiği sonucuna ulaşılmıştır. Sonuç olarak öğretmenlerin hizmetkâr bir lider olarak okul yöneticilerinden beklentilerinin yüksek olduğu ve farklı becerilere sâhip olmalarını bekledikleri söylenebilir. Bu doğrultuda okuluna hizmetkâr lider olarak katkı sunan bir yöneticinin beşerî, kavramsal ve teknik becerilerin tamamında yeterli olması gerektiği anlaşılmaktadır. Bu doğrultuda eğitim yöneticisi seçiminde, yetiştirilmesinde ve geliştirilmesinde bu becerilerin tamamının dikkate alınması gerekmektedir.

Anahtar Kelimeler: Hizmetkâr liderlik; Okul yöneticisi; Öğretmen.

\title{
Teacher's Opinions Related to Servant Leadership Qualities of Primary School Principals
}

\begin{abstract}
The aim of this study is to determine the properties of servant leadership that primary school administrators should have according to the views of primary school teachers. The study has been designed with a qualitative research approach. One of the Qualitative research designs, the Phenomenon approach which is appropriate to the nature of the research has been used in the study, six open-ended questions and semi-structured interview form consisting of sub-questions related to these questions prepared by the researcher have been used to collect data. One of the oriented sampling methods, snowball sampling method has been used in this study. In this context interviews have been conducted with 10 teachers who took part in various projects during the 2015-2016 academic year in primary schools in the central district of Sanlıurfa province. Questions related to the five dimensions (empathy, altruistic behavior, modesty, justice, honesty) have been posed to the Participants to determine the servant leadership properties of the school administrators. The data obtained at the end of the interview have been classified in these 5 themes via descriptive analysis. In the study, primary school administrators should have some properties such as having
\end{abstract}


the skills of effective communication, having the professional knowledge and skills, being cooperative, being fair, having self-criticism, solving problems and assuring according to the views of primary school teachers.

Keywords: Servant leadership; School administrators; Teachers.

\section{Extended Summary}

\section{Purpose}

Servant leadership is a type of leadership that has emerged as a result of the change and transformation in the leadership understanding of the $21^{\text {st }}$ century. Serving humanity lies at the essence of servant leadership that was put forth by Greenleaf. School manager as a servant leader should contribute to the development of their institution based on the understanding of placing your soul in your job. As a servant leader, the school manager should play the role of a leader who meets the demands of the teachers, increases their motivations, develops their performances, values them, works with them to enable them to reach their goals and providing all opportunities for them. In this regard, it is thought that applying servant leadership at schools will contribute to enabling the schools to reach their goals. Based on this necessity, the objective of this study was to determine the servant leadership properties that primary school managers should possess according to the opinions of teachers.

\section{Method}

The qualitative study was carried out via phenomenology pattern. The participants of the study were comprised of 10 teachers selected via snowball sampling method. Semi-structured interview form was prepared by the researchers as a data acquisition tool. The study on evaluating the servant leadership behavior of school managers carried out by Ekinci (2015) was taken as a basis for preparing the semi-structured interview form. According to Ekinci (2015), the servant leadership behavior of school managers can be examined in five dimensions. These are empathy, altruistic behavior, justice, modesty and honesty. The interview questions were comprised of questions that cover these dimensions. Content validity of the form was provided based on the opinions of five faculty members after preparing the interview form. In addition, the interview form was applied on four teachers prior to the application in order to test its understandability and convenience for getting a response. The data of the study were recorded via a voice-recorder based on 
the questions specified in the interview form after the consent of the participants were taken. The interviews were carried out by the researcher at a location where the participants can feel comfortable one by one with each participant. The interviews last on average 38 minutes and the total recorded data is 383 minutes. Descriptive analysis was used for analyzing the acquired data.

\section{Results}

According to the primary school teachers who participated in the study, there are 20 properties that a school manager should possess as a leader. In addition to personal properties such as possessing an effective communication skill, empathy and justice, vocational properties such as having knowledge on the field in question were put forth as the most desired properties. The participants emphasized that school managers should first possess the attribute of making shared decisions in order for him/her to be able to actualize the empathy dimension of leadership. It was put forth that the school managers should possess problem solving skills for the altruistic behavior dimension; the ability for self-criticism for modesty dimension; being just/objective for the justice dimension; being reassuring, just and having the ability to make task distributions according to personal properties for the honesty dimension.

\section{Discussion}

It is understood that communication skill is among the primary skills that school managers should possess. School managers should turn effective communication into a skill in order to develop the organizations and to ensure that they are improved and continue their existence. Another desired attribute that is in close relation with effective communication is showing empathy. It can be put forth that it is important for school managers to show empathy in order to ensure that schools function properly. When these two properties are considered together, it can be put forth that personal properties are most important for school managers as leaders. Being respectful, modest, tolerant, attract attention as personal properties among the 20 categories put forth by the participants. Thus, it can be stated that school managers should first value teachers in order to be valued back as leaders. Properties that ease putting forth the already existing potential attract attention for managing others while valuing them, in other words for governance and carrying out all sub-dimensions of servant leadership.

\section{Conclusion}

It was understood in this study, related with servant leadership that 
being a leader actually requires serving the team members to reach the organizational goals as has been put forth in various other studies. This shows that personal properties are more effective than vocational and technical properties in transforming a manager into a leader. Personal properties can be gained by experience based on application rather than short term trainings. In-service training (at work, full time) can be suggested in this study rather than in-service teaching (courses, seminars, etc.) as has been put forth in many studies.

\section{Giriş}

Dünyayı etkileyen küreselleşme olgusu toplumların hızlı bir değişim süreci yaşamasına neden olmaktadır. Toplumsal yapıda meydana gelen değişmeler ve gelişmeler eğitim sistemlerini ve sistemin yöneticilerinin davranış ve rollerini de etkilemiştir (Çelik, 2013, s.161). Çok hızlı değişimlere uyum sağlamaya çalışan eğitim yöneticileri de çağa ayak uydurmak ve kendini geliştirmek zorunda kalmıştır. Dolayısıyla okul yöneticilerinin değişen ve gelişen dünya sisteminde uluslararası bir bakış açısına sâhip olması gerektiği söylenebilir. Okul müdürlerinin okulun işleyişinde doğrudan veya dolaylı birçok etkisi vardır. Okul müdürü, okulun amaçlarının gerçekleşebilmesi için paydaşlarının sâhip oldukları bedensel ve zihinsel güçlerini harekete geçirmelidir. Bunu gerçekleştirmek ve bu yolla etkili bir okul oluşturmada müdürlerin liderlik özelliklerinin önemli bir etkisinin bulunduğu bilinmelidir (Şişman, 2012, s.132).

Türkiye'de giderek azalsa da halen yaygınlığını koruyan anlayışa göre okul müdürü belirli görev tanımları olan ve bunların dışına çıkmayan, okulun bütçesini plânlayan, etkinlikleri düzenleyen, derslerin iyi bir şekilde işlenmesi için önlemler alan, yasa ve yönetmelikleri birebir uygulayan, sınırları belli olan ve risk almayan bir yöneticidir (Taha ve Gedikoğlu, 2009). Oysa liderlik sadece görevin yapılması değil, gerektiğinde risk alan, ön plâna çıkan, bütün seçenekleri değerlendiren, yeni hedefler belirleyen ve insanları o hedeflerin etrafında toplayabilen kişilerdir. Günümüzde de her okul yöneticisinin birer lider olması gerektiği yaygın bir görüştür (Argon, 2004; Bakan ve Büyükbeşe, 2010; Balyer ve Gündüz, 2013; Can, 2010; Çelik, 2013; Okçu, 2011; Sincar, 2015; Taha ve Gedikoğlu, 2009).

21. yüzyılda liderlerden farklı roller beklenmektedir. Geleneksel anlayışlar artık varlığını devam ettiremeyip yok olmaya doğru gitmektedir. Geleneksel yönetim anlayışlarının ortadan kalkmaya başlamasıyla insanlar yeni 
liderlik yaklaşımları geliştirmeye başlamıştır. Yeni liderlik yaklaşımları, her ne kadar farklı davranışların özel etkisine odaklanıyor olsa da özünde her düzeydeki yöneticilerden bir lider olarak belirli davranışlar beklemektedir. $\mathrm{Bu}$ liderlik yaklaşımlarından okul yöneticilerinin de etkilendiği ifade edilebilir. Okulda yaşanan çeşitli sorunları ortadan kaldırarak, okuldaki eğitimin sürekli olarak geliştirilmesi ve iyileştirilmesini sağlayan etkili, yaratıcı, vizyon sâhibi, özendirici, entelektüel, bilgili, ilkeli liderlerin rehberlik ettiği yöneticilerin varlığı oldukça önemlidir (Girard, 2000, akt; Cerit, 2007). Bu bağlamda okul müdürlerinin liderlik davranışları sorgulanmaya başlanmış ve bu davranışlara yönelik çeşitli araştırmalar geliştirilmiştir. Bu araştırmalar sonunda da yeni liderlik biçimleri ortaya çıkmıştır (Özkan, 2016). Vizyoner liderlik, etik liderlik, dönüştürücü liderlik, karizmatik liderlik, ruhsal liderlik, öğrenen liderlik, teknoloji liderliği vb. bunlardan bazılarıdır. Bu liderlik biçimlerinden biri de ulusal alanyazında birçok araştırmaya konu olmuş hizmetkâr liderliktir (Akdöl, 2015; Akyüz, 2012; Akyüz, 2014; Aslan ve Özata, 2011; Bakan ve Doğan, 2012; Balay, Kaya ve Yılmaz, 2014; Baytok ve Ergen, 2013; Büyüktatl, 2015; Cerit, 2007, 2008; Coşkunlar, 2011; Çetin, 2014; Çiçek, 2015; Dal, 2014; Dal ve Çorbacioğlu, 2014; Dinçer ve Bitirim, 2007; Duyan, 2012; Duyan ve Dierendonck, 2014; Ekinci, 2015; Ergen, 2013; Fındıkç1, 2013; Kahveci, 2012; Kırmızı, 2014; Sanı, Atan, Çalışkan ve Yozgat, 2013; Öner, 2008; Özmutlu, 2011; Polat, 2013; Uzun, 2015; Y1lmaz, 2013). Çalışmalara genel olarak bakıldığında hizmetkâr liderliğin son on yıl içerisinde yeni bir liderlik tarzı olarak ulusal alanyazında yerini aldığı ifade edilebilir.

Hizmetkâr liderlik içerisinde bulunduğumuz 21. yüzyılın liderlik anlayışındaki değişim ve dönüşümün sonunda ortaya çıkmış olan bir liderlik tarzıdır. Liderlerin hizmetkâr/hizmetçi olarak ifade edilmesi yüzlerce yıl eskiye dayanmaktadır. Muhtemelen, hizmetkâr liderliği destekleyen değerler de Budizm, Hıristiyanlık, Hinduizm, İslâm ve Musevîlik gibi büyük dinlerden alınmıştır (Öner, 2008). İlk olarak 1970 yılında Greenleaf tarafindan ortaya atılan Hizmetkâr liderlik stilinin özünde öncelikle insanlığa hizmet etme anlayışı bulunmaktadır (Sanı ve ark., 2013). Greenleaf (1977) hizmetkâr liderlik kavramını ilk olarak Herman Hesse'nin Doğu'ya Yolculuk adlı hikâyesinden esinlenerek "Hizmetkâr Olarak Lider" adlı eserinde tanıtmıştır. Hikâyeye göre ana karakter olan Leo, yolculuğa çıkmış olduğu bir grup gezgine karş1 gösterdiği ilgili tavrı ve davranışları ile herkesi etkilemiştir. Daha sonra Leo'nun aniden ortadan yok olması ile grup lidersiz kalmış ve onun gizli liderliği ortaya çıkmıştır (Öner, 2008, s.8). Greenleaf'a (1998) göre 
hizmetkâr lider empati kuran, takipçisini etkin olarak dinleyen, takipçilerine duygusal destek veren, takipçisinin gelişimini önemseyen, yapacakları işe inanan ve kendilerini bir ekip olarak görmelerini sağlayan bir kişidir. Bu tip liderler örgütte ortak değerler yaratır, takım çalışmasını benimsetir, astlarının gelişimi için imkânlar sağlar ve karar verme sürecine rehberlik ederler (Özmutlu, 2011). Bununla birlikte ve hizmetkar liderlik için en önemlisi, bir lider olarak takipçilerine bencillikten uzak ve karşılık beklemeksizin hizmet etmeyi ilke edinmişlerdir.

Hizmetkâr lider olarak okul müdürü yapılan işe ruhunu koyma anlay1şından hareketle kurumlarının gelişmesine katkı sağlamalıdır (Dinçer ve Bitirim, 2007). Bu bağlamda müdür öğretmenlerin ihtiyaçlarını karşılayan, motivasyonlarını arttırtan, performanslarını geliştiren, onlara değer veren, onların hedeflerinin gerçekleştirebilmesinde rol oynayan ve bütün imkânları öğretmenlerin hizmetine sunan bir lider konumunda olmalıdır. Bu açıdan hizmetkâr liderliğin okullarda uygulanmasının, okulun amaçlarına ulaşmasına katkı sağlayacağı düşünülmektedir. Bu doğrultuda araştırmanın problemi "İlkokul yöneticilerinin sâhip olması gereken hizmetkâr liderlik özelliklerine ilişkin öğretmen görüşleri nelerdir?” şeklindedir. Dolayısıyla bu araştırma ilkokul yöneticilerinin sâhip olması gereken hizmetkâr liderlik özelliklerini belirlemek amacıyla yapılmıştır.

Alanyazın incelendiğinde eğitim alanında hizmetkâr liderlikle ilgili çalışmaların oldukça sınırlı olduğu görülmektedir (Akyüz, 2012; Balay, Kaya ve Y1lmaz, 2014; Büyüktatlı, 2015; Cerit, 2007, 2008, 2009; Çiçek, 2015; Ekinci, 2015; Kahveci, 2012; Polat, 2013). Çalışmalar genel olarak incelendiğinde hizmetkâr liderliğin çeşitli değişkenlerle ilişkisinin incelendiği metodolojik olarak nicel yöntemlerin ağırlıklı olduğu görülmüştür. Buradan hareketle çalışmada, okul yöneticileri ile yoğun etkileşim süreci yaşayan öğretmenlerin görüşlerinin derinlemesine incelenmesi bir gereklilik olarak görülmüştür.

\section{Yöntem}

Bu bölümde, araştırmanın modeli, örneklemi, veri toplama aracı, verilerin toplanması ve verilerin analizi ile ilgili bilgiler bulunmaktadır.

\section{Araştırmanın Modeli}

Araştırma, nitel araştırma yaklaşımıyla oluşturulmuştur. Nitel araştırma yöntemleri, araştırmanın yapıldığı doğal ortamı anlamaya, tanımaya ve araştırmanın sonuçlarına olan etkilerini açıklamaya duyarlı olduğundan 
eğitsel konuları çok boyutlu olarak ortaya koyarlar. Bu yönü ile eğitim araştırmalarında yaygın olarak kullanılan bir araştırma türüdür (Işskoğlu, 2005).

$\mathrm{Bu}$ araştırma, ilkokul öğretmenlerinin görüşlerine göre okul yöneticilerinin sâhip olması gereken hizmetkâr liderlik özelliklerini belirlemek amacıyla nitel araştırma desenlerinden olgubilim deseni ile yapılmış bir çalışmadır. Olgubilim deseni, farkında olduğumuz ancak derinlemesine ve ayrıntılı bir anlayışa sâhip olmadığımız olgular hakkında bilgi edinmemizi sağlar (Yıldırım ve Şimşek, 2013, s.78).

\section{Araştırmanın Katılımcıları}

Nitel araştırma desenlerinden olgu bilim deseni ile yapılan bu araştırmanın katılımcılarını kartopu örneklem yoluyla seçilen 10 öğretmen oluşturmuştur. Kartopu örnekleme, araştırma problemine ilişkin bilgi kaynağ olabilecek bireylerin saptanmasında etkilidir. Kartopu örneklemesi "Bu konuda kimler bilgi sâhibi olabilir?” sorusu sorularak yapılır. (Yıldırım ve Şimşek, 2013, s.140). Dolayısıyla bu araştırmada, Millî Eğitim Bakanlığına (MEB) bağlı kurumlarda çalışıp, çeşitli projelerde görev almış öğretmenlerin örnekleme dâhil edilmesi kararlaştırılmıştır. Katılımcıların MEB'e bağlı kurumlarda, çeşitli projelerde görev almış öğretmenlerden seçilmesinin ana sebebi, proje odaklı bir çalışmada müdür ile olan etkileşimin doğal derinliği olarak ifade edilebilir. Veri toplamak üzere, Şanlıurfa MEM Arge bölümünden ve çevresindeki öğretmenlerden destek alarak yaptığı projelerle öne çıkan öğretmen isimlerine ulaşılmıştır. İsimlerin ve bulguların tekrar etmeye başladığı noktada 10 katılımcıyla görüşmelere son verilmiştir. Araştırmacıların kodlanmasında "K"; katılımcıyı ifade etmektedir. Buna göre görüşmeye katılanlar görüşme sırasına göre "K-1”, “K-2”, “K-3”, “K-4”, “K-5”, “K-6”, “K-7”, “K-8”, “K-9” ve “K-10” şeklinde kodlanmıştır.

\section{Veri Toplama Araçları}

İlkokul öğretmenlerinin görüşlerine göre okul yöneticilerinin sâhip olması gereken hizmetkâr liderlik özelliklerini belirlemek amacıyla yarı yapılandırılmış görüşme formu oluşturulmuştur. Yarı yapılandırılmış görüşme, araştırmacı tarafından önceden belirlenmiş ya da görüşme esnasında ortaya çıkan konulara göre yeni soruların da sorulabildiği bir görüşme yöntemidir (Güler, Halıcıoğlu ve Taşğın, 2013, s.113). Yarı yapılandırılmış görüşme formunun oluşturulmasında Ekinci (2015) tarafindan yapılan okul müdürlerinin hizmetkâr liderlik davranışlarını değerlendirmeye yönelik çalışma temel alınmıştır. Ekinci (2015)'ye göre okul müdürlerinin hizmetkâr liderlik dav- 
ranışları beş boyutta incelenebilmektedir. Bunlar; empati, özgecil davranışlar, alçakgönüllülük, adâlet ve dürüstlüktür. Görüşme soruları bu boyutları kapsayan sorulardan oluşturulmuştur. Sonuç olarak görüşme formunda altı soru yer almıştır. İlk soru öğretmenlerin liderlikle ilgili görüşlerini belirtebilecekleri açık uçlu genel bir soru olarak hazırlanmıştır. İkinci soru hizmetkâr liderliğin empati boyutuyla, üçüncü soru özgecil davranışlar boyutu ile, dördüncü soru alçakgönüllülük boyutu ile, beşinci soru adâlet boyutu ile, altınc1 soru da dürüstlük boyutu ile ilgili olarak hazırlanmıştır.

Görüşme formu oluşturulduktan sonra alanında uzman beş öğretim üyesinin görüşlerinden yararlanılarak formun kapsam geçerliliği sağlanmıştır. Ayrıca görüşme formu uygulama öncesi dört öğretmene uygulanıp anlaşılabilirliği ve yanıt almaya elverişliliği bakımından kontrol edilmiştir.

\section{Verilerin Toplanması}

Araştırma amacı doğrultusunda nitel araştırma veri toplama yöntemlerinden görüşme tekniği kullanılmıştır. Görüşme bir bireyin iç dünyasına girerek, onun bakış açısını anlamak için yapılmaktadır. Aynı zamanda görüşme olgubilim araştırmalarında en sık kullanılan veri toplama aracıdır. Görüşme gözlemleyemediğimiz davranışlar, duygular veya insanların etraflarındaki dünyayı nasıl ifade ettiklerini öğrenmek amacıyla yapılır (Merriam, 2013, s.86). Araştırmanın verileri, görüşme formunda belirtilen sorulara dayalı olarak, görüşmecilerden izin alınarak ses kayıt cihazına kaydedilmiştir. Ses kayıtları, herhangi bir ifadeyi tekrar dinlemede ve alıntı yapmada oldukça kullanışlıdır (Bell, 1999). Görüşmeler katılımcıların rahat edebilecekleri bir yerde, her bir katılımcı ile araştırmacı tarafindan tek tek yapılmıştır. Görüşmeler ortalama 38 dakika sürmekte olup toplam kayıtlı veri 383 dakikadır.

\section{Verilerin Analizi}

Görüşme kayıtlarının ayrıntılı olarak analiz edilebilmesi için öncelikle bilgisayar ortamında yazıya geçirilmiştir. Görüşmelerin yazıya geçirilerek deşifre edilmesi sonucunda 114 sayfalık ham veri elde edilmiştir. Bu yolla elde edilen verilerin çözümlenmesinde betimsel analiz kullanılmıştır. Betimsel analiz yöntemiyle yapılan görüşme çözümlemelerinde kelimelere, ifadelere, kullanılan dile, diyalogların yapısına ve özelliklerine, kullanılan sembolik anlatımlara ve benzetmelere dayanarak tanımlayıcı bir analiz yap1labilir (Kumbetoğlu, 2005). Betimsel analizde görüşülen kişilerin düşüncelerine doğrudan alıntılar yaparak yer verilir. 


\section{Araştırmanın Geçerlilik ve Güvenilirliği}

Nitel araştırmada geçerlilik araştırmacının araştırdığı konuyu olabildiğince yansız gözlemesi anlamına gelmektedir (Kirk ve Miller, 1986, akt; Yıldırım ve Şimşek, 2013, s.289). Araştırmada geçerliği sağlamak için; alanında uzman, birden fazla araştırmacı verilerin analizini birbirinden bağımsız olarak incelemiş, öğretmenlerin görüşlerinden doğrudan alıntılar yapılmış ve amaçlı örnekleme yöntemi kullanılmıştır. Güvenirlik ise aynı çalışmanın farklı gözlemciler tarafından ya da aynı gözlemci tarafından farklı zamanlarda yapıldığında benzer sonuçları vermesidir (Güler, Halıcıoğlu ve Taşğın, 2013, s.344). Araştırmanın güvenirliği sağlamak için; görüşme verileri ses kayıt tekniği kullanılarak elde edilmiş ve sonuçlarla bütünleştirilmiştir. Ayrıca araştırmacı dışında bir akademisyen tarafından veriler, ulaşılan yargı ve yorumlar ham verilerle karşılaştırılıp teyit edilmiştir.

Araştırmanın güvenilirliği sağlamak için katılımcı teyidi de yapılmıştır. Katılımcı teyidi katılımcılardan elde edilen verilere dayalı olarak araştırmacı tarafindan elde edilen kodların ve yapılan yorumların, katılımcılarla yeniden paylaşılarak test edilmesi olarak ifade edilebilir. $\mathrm{Bu}$ süreç araştırmacıya, katılımcıların görüşlerine dayalı olarak bulunan kategorilerin ve yapılan yorumların, gerçekten katılımcının ifadelerini yansıtıp yansıtmadığını ortaya koymak amacıyla yapılmaktadır (Lincoln ve Guba, 1985). Verilerin analizinin ardından katılımcılardan üçüyle yüz yüze görüşülmüş söyledikleri kendisiyle birlikte yeniden incelenerek belirlenen kategorilere ilişkin görüşleri alınmıştır. Ardından katılımcıların ifadeleri doğrultusunda gerekli düzenlemeler yapılmıştır.

\section{Bulgular}

$\mathrm{Bu}$ araştırmada öncelikle bir lider olarak okul yöneticisinin sâhip olmas1 gereken özelliklere, ardından hizmetkâr liderliğin her bir alt boyutuna ilişkin bulgulara yer verilmiştir.

\section{Bir Lider Olarak Okul Yöneticisinin Sâhip Olması Gereken Özel- liklere İlişkin Bulgular}

Araştırmaya katılan ilkokul öğretmenlerine göre bir lider olarak okul yöneticisinin sâhip olması gereken özelliklere ilişkin bulgular Tablo 1'de gösterilmiştir. 
Tablo 1. Bir Lider Olarak Okul Yöneticisinin Sâhip Olması Gereken Özellikler

\begin{tabular}{ll}
\hline Kategoriler & f \\
\hline Etkili İletişim Becerisine Sâhip Olma & $6_{K-1,3,6,8,9,10}$ \\
Empati Kurma & $6_{K-1,3,4,5,9,10}$ \\
Alan Bilgisi & $5_{K-3,5,6,9,10}$ \\
Adil Olma & $5_{K-2,3,5,6,7}$ \\
Örnek/Model Olma & $4_{K-3,5,9,10}$ \\
Problem Çözme Becerisine Sâhip Olma & $4_{K-5,6,7,9}$ \\
Dürüst Olma & $3_{K-2,3,9}$ \\
İşbirlikçi Olma & $3_{K-1,7,9}$ \\
Disiplinli Olma & $3_{K-4,8,10}$ \\
Hoşgörülü Olma & $3_{K-4,5,10}$ \\
Vizyon Sâhibi Olma & $2_{K-1,2}$ \\
Demokratik Olma & $2_{K-3,9}$ \\
Gelişime Açık Olma & $2_{K-3,10}$ \\
Saygılı Olmak & $2_{K-3,7}$ \\
Yaratıcı Düşünmeye Sâhip Olma & $2_{K-4,10}$ \\
Alçak Gönüllü Olma & $2_{K-7,9}$ \\
Tutarlı Olma & $2_{K-5,9}$ \\
Karakterli Olma & $1_{K-1}$ \\
Risk Alabilme & $1_{K-10}$ \\
Mizah Yeteneğine Sâhip Olma & $1_{K-10}$ \\
\hline Toplam Kategori = 20 & $\mathrm{N}=60$ \\
\hline
\end{tabular}

Araştırmaya katılan 10 öğretmenden 6'sı bir lider olarak okul yöneticisinin etkili iletişim becerisine sâhip olması gerektiğini ifade etmiştir. Katılımcılar okul içerisinde iletişimin çok önemli olduğunu, yöneticilerin öğretmenler ve personellerle etkili iletişim kurarak onları anlaması gerektiğini ifade etmiştir. Örneğin, "Evvelâ insan ilişkilerinin iyi olması, insan ilişkileri konusunda bilgi ve beceriye sâhip olması lâzım. İnsan ilişkileri konusundaki bilgi ve becerilerini tavır ve davranışlarıyla karşısındakine yansıtması lazım." $(\mathrm{K}-1)$

Araştırmaya katılan 10 öğretmenden 6'sı bir lider olarak okul yöneticisinin empati kurması gerektiğini ifade etmiştir. Katılımcılar okul yöneticilerinin empati kurarak öğretmenleri daha iyi anlayabileceğini düşünmektedir. Örneğin, "Empati yeteneğinin iyi olması lazım. Empati kurup neden onun o 
durumda olduğunu düşünebilirsen ögretmeninle iletişimin artar. Öğretmenin de bu sefer okula bağımlılı̆̆ı artar.” (K-10)

Araştırmaya katılan 10 öğretmenden 5'i bir lider olarak okul yöneticisinin alan bilgisine sâhip olması gerektiğini ifade etmiştir. Araştırmada yer alan katılımcılardan bazılarının alan bilgisi kategorisine ilişkin söylemleri şu şekildedir: "Okul yöneticisi en başta kanun ve yönetmeliklerin belirlediği kurallara çok iyi bir şekilde hâkim olup, bunları tarafsız bir şekilde bütün ögretmenlere uygulamalıdır.” (K-5)

Araştırmaya katılan 10 öğretmenden 5'i bir lider olarak okul yöneticisinin adil olması gerektiğini vurgulamıştır. Araştırmada yer alan katılımcılardan bazılarının adil olma hakkındaki görüşleri şu şekildedir: "Bana göre belli bir duruşu olmall. Kişilere göre eğilip bükülmemeli.” (K-3), “Okul yöneticisi âdil olmalı, hakkaniyet içerisinde olmalıdır. Yani kendisinin dışartdaki algisı herkeste aynı şeyi uyandırmalı, diye ekleyebilirim.” (K-7)

Araştırmaya katılan 10 öğretmenden 4'ü bir lider olarak okul yöneticisinin iyi bir model olması gerektiğini ifade etmiştir. Katılımcılar okul yöneticilerinin giyimiyle, kuşamıyla, konuşmasıyla ve duruşuyla örnek bir kişi olması gerektiğini ifade etmiştir. Örneğin: “... bana göre bir lider duruşuyla, klyafetiyle, konuşmastyla çevresine örnek olmalı diye düşünüyorum.” (K-3), "Kılık klyafetinizin düzgün olması lâzım. Çünkü örnek bir kişi olmalısın, model olmalısın. Çalışanlara örnek bir model olacaksınız ki çalışanlar sizi örnek alıp etkilensinler.” (K-9)

\section{İlkokul Yöneticilerinin Sâhip Olması Gereken Hizmetkâr Liderli- ğin Empati Boyutuna İlişkin Bulgular}

Araştırmaya katılan ilkokul öğretmenlerinin görüşlerine göre ilkokul yöneticilerinin sâhip olması gereken hizmetkâr liderliğin empati boyutuna ilişkin bulgular Tablo 2'de gösterilmiştir.

Tablo 2'de de görüleceği gibi araştırmaya katılan 10 öğretmenin 8'i ilkokul yöneticilerinin sâhip olması gereken hizmetkâr liderlik özelliklerinin empati boyutuna ilişkin ortak karar alma/işbirlikçi olma kategorisini ön plâna çıkarmıştır. Katılımcılar okul yöneticilerinin öğretmenlerle ve diğer çalışanlarla ortak karar alarak, iş birliği yapmaları gerektiğini belirtmiştir. Örneğin: "Olması gereken ortak karar almaktır. Okul yöneticileri okul öğretmenleri ile beraber ortak karar alıp bunu okul içerisinde uygularlarsa ögretmenlerle okul idaresi arasındaki köprü çok sağlam olmuş olur." (K-5), "Şimdi her 
insanın insan olmasından kaynaklı düşünceleri vardır. Bunu da karşıllklı konuşarak çözmelidir.” (K-9)

Tablo 2. Okul Yöneticilerinin Hizmetkâr Liderliğin Empati Boyutunu Gerçekleştirebilmesi İçin Gerekli Özelliklere İlişkin Bulgular

\begin{tabular}{ll}
\hline Kategoriler & f \\
\hline Ortak Karar Alma/İşbirlikçi Olma & $8_{K-1,4,5,6,7,8,9,10}$ \\
İyi Bir Dinleyici Olma & $4_{K-1,5,8,9}$ \\
Etkili İletişsim Becerisine Sâhip Olma & $4_{K-1,2,6,9}$ \\
Anlayışılı Olma & $4_{K-1,4,7,8}$ \\
Açık ve Net Olma & $3_{K-3,4,5}$ \\
Paylaşımc1 Olma & $2_{K-2,6}$ \\
Sayg11 Olma & $2_{K-3,9}$ \\
Mesafeli Olma & $2_{K-3,6}$ \\
Samimi Olma & $2_{K-3,7}$ \\
Çözüm Bulma/ Yol Gösterme & $2_{K-5,6}$ \\
Dürüstlük & $1_{K-4}$ \\
Âdil Olma & $1_{K-4}$ \\
Güven Verme & $1_{K-5}$ \\
Ön Yargısı Olma & $1_{K-6}$ \\
Alçak Gönüllü Olma & $1_{K-7}$ \\
Mizah Yeteneğine Sâhip Olma & $1_{K-10}$ \\
\hline Toplam Kategori=16 & $\mathrm{N}=39$ \\
\hline
\end{tabular}

Araştırmaya katılan 10 öğretmenin 4'ü ilkokul yöneticilerinin sâhip olması gereken hizmetkâr liderlik özelliklerinin empati boyutuna ilişkin iyi bir dinleyici olma kategorisini ön plâna çıkarmıştır. Katılımcılar okul yöneticilerinin öğretmenleri ve diğer çalışanları iyi bir şekilde dinleyerek onların sorunlarını çözmesini ve böylece onlara değer verdiğini göstermesi gerektiğini belirtmiştir. Örneğin, "Okul yöneticisi, ögretmeni dinledikten sonra mutlaka bu işin çözümü için yeni bir şeyler ortaya koyması gerekir ki hizmetkâr liderlerin en büyük özelliklerinden birisi budur.” (K-5)

Araştırmaya katılan 10 öğretmenin 4'ü ilkokul yöneticilerinin sâhip olması gereken hizmetkâr liderlik özelliklerinin empati boyutuna ilişkin etkili iletişim becerisine sâhip olma kavramını ön plâna çıkarmıştır. Katılımcılar okul yöneticilerinin öğretmenlerle ve diğer çalışanlarla etkili iletişim kurmaları gerektiğini belirtmiştir. Örneğin, “Ben müdür olsam ögretmenler odası benim makam odam olur. Çünkü ögretmenler teneffüse çıktı̆̆ıda benim 
odama kapıyı vurup girmektense ben onları yanında olsam her kirk dakikaya bir onlarla iletişim kursam.” (K-6)

\section{İlkokul Yöneticilerinin Sâhip Olması Gereken Hizmetkâr Liderli- ğin Özgecil Davranışlar Boyutuna İlişkin Bulgular}

Araştırmaya katılan ilkokul öğretmenlerinin görüşlerine göre ilkokul yöneticilerinin sâhip olması gereken hizmetkâr liderlik özelliklerinin özgecil davranışlar boyutuna ilişkin bulgular Tablo 3 'de gösterilmiştir.

Tablo 3. Okul Yöneticilerinin Hizmetkâr Liderliğin Özgecil Davranışlar Boyutunu Gerçekleştirebilmesi İçin Gerekli Özelliklere İlişkin Bulgular

\begin{tabular}{ll}
\hline Kategoriler & f \\
\hline Problem çözme becerisine sâhip olma & $8_{K-2,3,5,6,7,8,9,10}$ \\
Adanmışlık & $4_{K-1,2,5,7}$ \\
İstekleri karşılama & $3_{K-1,3,4}$ \\
Fikir alışverişinde bulunma & $3_{K-4,5,6}$ \\
İhtiyaçları giderme & $2_{K-1,8}$ \\
İyi model olma & $2_{K-1,9}$ \\
Sakinlik & $2_{K-3,7}$ \\
Yönlendirme & $2_{K-4,7}$ \\
İnisiyatif alma & $2_{K-5,9}$ \\
Yeterli bilgi ve beceriye sâhip olma & $2_{K-1,9}$ \\
Önlem alma & $1_{K-1}$ \\
Adil davranma & $1_{K-2}$ \\
Dürüstlük & $1_{K-2}$ \\
Farklı bakış açısına sâhip olma & $1_{K-3}$ \\
Tessvik etme & $1_{K-5}$ \\
Ödüllendirme & $1_{K-6}$ \\
Personeli sâhiplenme & $1_{K-7}$ \\
Empati kurma & $1_{K-10}$ \\
\hline Toplam Kategori= 18 & $\mathrm{N}=38$ \\
\hline
\end{tabular}

Araştırmaya katılan 10 öğretmenin 8'i ilkokul yöneticilerinin sâhip olması gereken hizmetkâr liderlik özelliklerinin özgecil davranışlar boyutuna ilişkin problem çözme becerisine sâhip olması gerektiğini belirtmiştir. Katılımcılar ilkokul yöneticilerinin okulda yaşanabilecek olası problemlere karşı çözüm üretebilme becerisine sâhip olmaları gerektiğini belirtmiştir. Örneğin: “... sorunu çözmek için okul müdürlerinin mutlaka liderlik becerilerini çok iyi bir şekilde kullanıp, mutlaka ve mutlaka acil bir çözüm önerisi üretip o ânda 
sorunu çözmesi gerekiyor.” (K-5), “Okul yöneticisi öncelikle çözüm odaklı olmalıdır. Çözüme alternatif çözümler üretmelidir.” (K-6)

Araştırmaya katılan 10 öğretmenin 4'ü ilkokul yöneticilerinin sâhip olması gereken hizmetkâr liderlik özelliklerinin özgecil davranışlar boyutuna ilişkin adanmış olma özelliğini belirtmiştir. Katılımcılardan bazılarının okul yöneticilerinin adanmış olma özelliğine ilişkin söylemleri şu şekildedir: " $L i$ derlikte öncelikli olarak bir adanmışlık söz konusudur. Lider olarak yapılmakta olan işe adanmak zorundasınızdır.” (K-2)

Araştırmaya katılan 10 öğretmenin 3'ü ilkokul yöneticilerinin sâhip olması gereken hizmetkâr liderlik özelliklerinin özgecil davranışlar boyutuna ilişkin fikir alışverişinde bulunma kategorisini belirtmiştir. Örneğin, “ $\ddot{O} \breve{g}$ retmenlerin görüşü alınır. Okul yöneticileri okulun yönetimi yani okul kurallarını, okuldaki düzeni devam ettirmek zorunda oldukları için mantıklı bir şeyse kabul ederler. Ĕger olmayacak bir şeyse öğretmenlere bunu doğru bir şekilde anlatmalıdirlar." (K-5)

Araştırmaya katılan 10 öğretmenin 2'si ilkokul yöneticilerinin sâhip olması gereken hizmetkâr liderlik özelliklerinin özgecil davranışlar boyutuna ilişkin iyi model olma kategorisini belirtmiştir. Katılımcılardan birinin iyi model olma özelliğine ilişkin söylemleri şu şekildedir: "Yöneticinin, öğretmenleri kendisine bağlaması lazım. Ben her zaman bir idarecinin okula geldiği zaman bacakları çemremiş, elinde firça yerleri temizlerken veya bir yerleri silerken görmek isterim. Bunları görünce elbette biz de taşın altına elimize koyarzz." (K-1)

Kat1lımcilardan 2'si ilkokul yöneticilerinin sâhip olmas1 gereken hizmetkâr liderlik özelliklerinin özgecil davranışlar boyutuna yönelik okul yöneticisinin sakin olmaları gerektiğini belirtmiştir. Örneğin, “Okul yöneticisi bence öncelikle sakin olmall. Konuyu tüm bakış açıları ile anlamaya çalışmall. Bu ögretmen gözüyle de olur, öğrenci gözüyle de olur. Bu sorunun boyutuna göre değişir.” (K-3)

Araştırmaya katılan 10 öğretmenin 2'si ilkokul yöneticilerinin sâhip olması gereken hizmetkâr liderlik özelliklerinin özgecil davranışlar boyutuna ilişkin inisiyatif alma özelliğini belirtmiştir. Örneğin, "Okulda mutlaka okul idarecisinin, yani yöneticinin inisiyatif alması gereken konular oluyor. Bu durumda okul müdürleri elini taşın altına koymalı, inisiyatif kullanmalıdır." (K-5) 


\section{İlkokul Yöneticilerinin Sâhip Olması Gereken Hizmetkâr Liderli- ğin Alçak Gönüllülük Boyutuna İlişkin Bulgular}

Araştırmaya katılan ilkokul öğretmenlerinin görüşlerine göre ilkokul yöneticilerinin sâhip olması gereken hizmetkâr liderliğin alçak gönüllülük boyutuna ilişkin bulgular Tablo 4'te gösterilmiştir.

Tablo 4. Okul Yöneticilerinin Hizmetkâr Liderliğin Alçak Gönüllülük Boyutunu Gerçekleştirebilmesi İçin Gerekli Özelliklere İlişkin Bulgular

\begin{tabular}{ll}
\hline Kategoriler & f \\
\hline Özeleştiri yapma & $10_{\mathrm{K}-1,2,3,4,5,6,7,8,9,10}$ \\
Takım çalışması/İşbirlikçi olma & $66_{\mathrm{K}-3,5,6,7,9,10}$ \\
Statüye önem vermeme & $6{ }_{\mathrm{K}-1,3,4,5,5,9,10}$ \\
Motive etme/Ödüllendirme & $4_{\mathrm{K}-1,6,7,10}$ \\
Sorumluluk sâhibi olma & $3_{\mathrm{K}-2,4,6}$ \\
Başkalarını düşünen/Fedakâr & $3_{\mathrm{K}-1,2,8}$ \\
İnsan ilişkilerine önem verme & 2 K-1,3 \\
Karakter sâhibi olma & $1_{\mathrm{K}-1}$ \\
Yol gösterici/Rehber olma & $1_{\mathrm{K}-5}$ \\
\hline Toplam Kategori=9 & $\mathrm{N}=36$ \\
\hline
\end{tabular}

Araştırmaya katılan öğretmenlerin hepsi ilkokul yöneticilerinin sâhip olması gereken hizmetkâr liderlik özelliklerinin alçak gönüllülük boyutuna ilişkin özeleştiri yapma kategorisini ifade etmiştir. Örneğin:

"Okul yöneticisi özeleştiri yaptı̆̆ zaman "Ben nerdeyim? Ne yaptım? Nasıl yapmalıyım? Nerede hata yaptım? Nerede doğru yaptım?” diye kendini sorgulamalıdır. Olumlu yönde de özeleştiri, olumsuz yönde de özeleştiri yapmak hizmetkâr lider olmanın özelliklerinden bir tanesi olduğu bilinmelidir.” (K-6)

“Özeleştiri yapmayan bir lider liderlik vasfinı kaybedip, kendi başına yaşayan bir insan olur.” (K-8)

Araştırmaya katılan 10 öğretmenin 6's1 ilkokul yöneticilerinin sâhip olması gereken hizmetkâr liderlik özelliklerinin alçak gönüllülük boyutuna ilişkin takım çalışması/işbirlikçi olma özelliğini belirtmiştir. Katılımcılar okul yöneticilerinin çalışanlarıyla işbirliği yaparak okulda bir takım ruhu oluşturabileceklerini düşünmektedir. Örneğin, "Mutlaka ve mutlaka başarı hiçbir zaman tek başına olmaz. Burada başarı hep beraber olur, başarısızlıkta hep beraber olur. Mutlaka o başarıda emeği geçen insanlarla okul yöneticisi o başarıyı paylaşmalıdır.” (K-5) 
Araştırmaya katılan 10 öğretmenin 6's1 ilkokul yöneticilerinin sâhip olması gereken hizmetkâr liderlik özelliklerinin alçak gönüllülük boyutuna ilişkin statüye önem verilmemesi gerektiğini belirtmişlerdir. Örneğin:

“...statüye önem vermeyen bir insan olmall. Hani ben müdürüm, sen öğretmensin şeklinde olmamalı.” (K-1)

“Ĕger karşısındaki ögretmenine, yönetici tepeden baklyorsa, yani tabiri caizse alt kademedekilere ikinci sinıf insan, kendisini bir üst makam olarak görüyorsa zaten alçak gönüllü, tevazu sâhibi olmasının imkânı yok.” (K-5)

\section{İlkokul Yöneticilerinin Sâhip Olması Gereken Hizmetkâr Liderli- ğin Adâlet Boyutuna İlişkin Bulgular}

Araştırmaya katılan ilkokul öğretmenlerinin görüşlerine göre ilkokul yöneticilerinin sâhip olması gereken hizmetkâr liderliğin adâlet boyutuna ilişkin bulgular Tablo 5’te gösterilmiştir.

Tablo 5. Okul Yöneticilerinin Hizmetkâr Liderliğin Adâlet Boyutunu Gerçekleştirebilmesi İçin Gerekli Özelliklere İlişkin Bulgular

\begin{tabular}{ll}
\hline Kategoriler & $\mathbf{f}$ \\
\hline Âdil/Objektif olma & $9_{\mathrm{K}-1,2,3,4,5,6,7,8,9}$ \\
Eşit olma & $7_{\mathrm{K}-2,3,4,5,6,7,9}$ \\
İletişim kurma & $6_{\mathrm{K}-1,2,3,5,7,8}$ \\
Sözünde durma & $6_{\mathrm{K}-2,3,4,6,7,10}$ \\
Tutarlı/İstikrarlı olma & $6_{\mathrm{K}-2,3,4,5,8,9}$ \\
Güven verme & $4_{\mathrm{K}-3,6,9,10}$ \\
Empati kurma & $3_{\mathrm{K}-2,3,9}$ \\
Dürüst olma & $2_{\mathrm{K}-2,9}$ \\
Samimi olma & $2_{\mathrm{K}-3,7}$ \\
\hline Toplam Kategori=9 & $\mathrm{N}=45$ \\
\hline
\end{tabular}

Araştırmaya katılan 10 öğretmenin 9'u ilkokul yöneticilerinin sâhip olması gereken hizmetkâr liderlik özelliklerinin adâlet boyutuna ilişkin âdil/objektif olma özelliğini ön plâna çıkarmıştır. Katılımcılar okul yöneticilerinin karşı âdil/objektif olmalarının öğretmenleri ve diğer çalışanları mutlu ettiğini düşünmektedir. Örneğin: "İyi bir değerlendirme için öğretmenin hakkını verebilmesi için âdil ve güvenilir bir değerlendirme yapması lâzım." (K-1), "Kesinlikle âdil olması lâzım, adâletli olması lâzım. Âdil olmadiğı 
durumlarda kendisine duyulan saygl sıfira iner.” (K-9)

Araştırmaya katılan 10 öğretmenin 7'si ilkokul yöneticilerinin sâhip olması gereken hizmetkâr liderlik özelliklerinin adâlet boyutuna ilişkin eşit olma ifadesini kullanmıştır. Katılımcılar okul yöneticilerinin öğretmenlere ve diğer çalışanlara karşı tarafsız, eşit bir şekilde davranmalarının olumlu katkıları olduğunu belirtirken, tersi davranışlarda olumsuz etkileri olacağını belirtmiştir. Örneğin, "Yönetici eşit olmazsa saygınlı̆̆ı da düşer. Dolayısıyla okul yöneticisi tarafsız olmalıdır.” (K-3)

Araştırmaya katılan 10 öğretmenin 6's1 ilkokul yöneticilerinin sâhip olması gereken hizmetkâr liderlik özelliklerinin adâlet boyutuna ilişkin iletişim kurma özelliğini ön plana çıkarmıştır. Örneğin, "Samimiyetiyle, içtenliğiyle, yaklaşımıyla, açık sohbetleriyle yani karşılıklı iletişimde mesafe koyarak değil, sevgi ruhuyla öğretmenlere yaklaşmalıdır.” (K-7)

\section{İlkokul Yöneticilerinin Sâhip Olması Gereken Hizmetkâr Liderli- ğin Dürüstlük Boyutuna İlişkin Bulgular}

Araştırmaya katılan ilkokul öğretmenlerinin görüşlerine göre ilkokul yöneticilerinin sâhip olması gereken hizmetkâr liderliğin dürüstlük boyutuna ilişkin bulgular Tablo 6' da gösterilmiştir.

Tablo 6'da da görüleceği gibi araştırmaya katılan 10 öğretmenin 8'i ilkokul yöneticilerinin sâhip olması gereken hizmetkâr liderlik özelliklerinin dürüstlük boyutuna ilişkin güven verme özelliğini ön plana çıkarmıştır. Katılımcılar okul yöneticilerinin öğretmenlere ve diğer çalışanlara söz ve davranışlarıyla güven vermesi aradaki bağı güçlendireceği düşünülmektedir. Örneğin: “... yöneticinin güven verici olması lâzım ki ben de ona gidip bir şeyleri açıkça söyleyeyim.” (K-4), "Güven duygusu, önem verdiği değer olmalıdır. Bizim okula karşı fedakârlığımızı ve bağlılığımızı arttırır.” (K-8)

Araştırmaya katılan 10 öğretmenin 8'i ilkokul yöneticilerinin sâhip olması gereken hizmetkâr liderlik özelliklerinin dürüstlük boyutuna ilişkin âdil olma özelliğini ifade etmiştir. Katılımcı okul yöneticisinin samimi olduğu öğretmene ayrıcalık göstermeyerek âdil olduğunu göstermesi gerektiğini ifade etmiştir. Örneğin, "Okul yöneticisi ögretmenin yakın arkadaşlı̆̆ına, onun muhabbetine değil; onun ögretmenlikte gösterdiği performansa, aktif olmaya, ögretmenin azmine, bütün bunlara bakarak karar vermelidir. Yok ĕger sendikaya, yok iyi dostluğa, yok şunun akrabası gibi düşüncelerinden birine sâhipse liderliği bırakın, birilerinin yalakası olur.” (K-8) 
Tablo 6. Okul Yöneticilerinin Hizmetkâr Liderliğin Dürüstlük Boyutunu Gerçekleştirebilmesi İçin Gerekli Özelliklere İlişkin Bulgular

\begin{tabular}{ll}
\hline Kategoriler & f \\
\hline Güven Verme & $8_{\mathrm{K}-1,2,3,4,6,7,8,9}$ \\
Âdil Olma & $8_{\mathrm{K}-2,3,4,5,6,7,8,9}$ \\
Kişilik Özelliklerine Uygun Görev Dağılımı Yapma & 7 K-1,2,3,4,5,9,10 \\
Tutarlı Olma & $6{ }_{\mathrm{K}-2,4,5,7,9,10}$ \\
Fikir Alışverişi/İletişim Kurma & $6_{\mathrm{K}-1,2,3,4,6,8}$ \\
Ödüllendirme & $5_{\mathrm{K}-3,4,5,6,10}$ \\
Doğruluk/Doğru Söyleme & $4_{\mathrm{K}-1,4,5,9}$ \\
Sözünde Durma & $4_{\mathrm{K}-2,5,8,10}$ \\
Görünür Olma & $3_{\mathrm{K}-1,3,5}$ \\
Samimi/İyimser Olma & $3_{\mathrm{K}-2,4,7}$ \\
Açık Sözlü Olma & $3_{\mathrm{K}-3,4,9}$ \\
Destek Olma & $3_{\mathrm{K}-4,6,7}$ \\
Fedakârlık & 2 K-9,10 \\
Ölçüte Göre Değerlendirme Yapma & $1_{\mathrm{K}-1}$ \\
Tarafsız Olma & $1_{\mathrm{K}-2}$ \\
Ön Yargisı Olma & $1_{\mathrm{K}-6}$ \\
İşbirlikçi Olma & $1_{\mathrm{K}-6}$ \\
Alçak Gönüllülük & $1_{\mathrm{K}-7}$ \\
\hline Toplam kategori=18 & $\mathbf{( N = 6 7 )}$ \\
\hline
\end{tabular}

Araştırmaya katılan 10 öğretmenin 7'si ilkokul yöneticilerinin sâhip olması gereken hizmetkâr liderlik özelliklerinin dürüstlük boyutuna ilişkin kişilik özelliklerine uygun görev dağılımı yapmak ifadesini ön plana çıkarmıştır. Katılımcılar okul yöneticilerinin çalışanlar arasında, kişilerin kabiliyetleri ölçüsünde görev dağılımı yapmanın işlerin iyi yapılması açısından önemli olduğunu düşünmektedir. Örneğin: "Okul yöneticisi öncelikle görev dağılımı yaparken vereceği işe göre bu değişir. Görevi o alanda yetkin olan, kabiliyeti olan kişilere vermesi gerekir.” (K-5)

Bulgulara genel olarak bakıldığında, okul yöneticilerinin hizmetkâr liderliğin alt boyutlarına ilişkin göstermesi gereken özelliklere ilişkin öğretmen görüşlerinin her bir alt boyutta benzer kategoriler oluşturduğu söylenebilir. Bu durumun nedeni hizmetkâr liderliğin her ne kadar alt boyutlara ayrılsada bir bütün olarak ele alınması gerektiği ile ilişkilendirilebilir. Diğer bir anlatımla herhangi bir alt boyutu tam anlamıyla yerine getirebilmek için diğer 
alt boyutlarında gerçekleştirilmesi gerektiği söylenebilir.

\section{Tartışma}

\section{Bir Lider Olarak Okul Yöneticisinin Sâhip Olması Gereken Özel- liklere İlişkin Tartışma}

Araştırmanın katılımcılarının, çeşitli projelerde görev almış ilkokul öğretmenleri, görüssleri analiz edildiğinde bir lider olarak okul yöneticisinin sâhip olması gereken özellikler arasında etkili iletişim becerisine sâhip olma öne çıkmaktadır. Özan (2006) tarafından yapılan ilköğretim okulu yöneticilerinin iletişim becerilerinin öğretmen ve yönetici görüşlerine göre değerlendirilmesiyle ilgili araştırmada eğitimde başarıya ulaşmada temel yollardan birisinin örgüt içinde olumlu bir iletişim ortamı sağlamaktan geçtiği vurgulanmıştır. Açıkalın ve Turan (2011)'da eğitim kurumlarında çalışanların, özelliklede okul yöneticilerinin sâhip olması gereken özelliklerin başında iletişim becerisinin olduğunu vurgulamıştır. Özdemir ve Sezgin (2002)'de öğretim lideri olarak okul yöneticisinin okulda etkili iletişimin kurulması için önderlik etmesi gerektiğini belirtmektedirler. Dolayısıyla örgütlerin gelişmesi, iyileşmesi ve varlığını sürdürebilmesi için okul müdürleri etkili iletişim becerisine sâhip olmayı beceri haline getirmelidir.

Araştırmada ortaya çıkan bir başka sonuca göre lider olarak okul yöneticisinin empati becerisine sahip olması gerektiğidir. Şimşek ve Altınkurt (2009) öğretmenlerin okul müdürlerinin iletişim becerilerine ilişkin görüşleriyle ilgili yaptıkları araştırmada okul müdürlerinin empati kurma becerilerinin orta düzeyde olduğu sonucuna ulaşmışlardır. Araştırmada okul müdürlerinin çalışanlarıyla üst düzeyde empati kurmalarının gerekliliği vurgulanmıştır. Yine Özdemir ve Sezgin (2002)'de okul yöneticisinin bir öğretim lideri olarak çalışanlarıyla empati kurarak onları anlaması gerektiğini vurgulamışlardır. Dolayısıyla okulun sağlıklı bir şekilde işleyişinde okul müdürlerinin empati kurmasının önemli olduğu ifade edilebilir.

Araştırmaya katılan öğretmenlerin görüşlerine göre bir lider olarak okul yöneticisinin sâhip olması gereken özellikler arasında alan bilgisi kategorisi yer almaktadır. Üstün ve Bozkurt (2005)'da okul yöneticilerinin meslek içinde sorun çözme becerilerini geliştirmek üzere alan bilgisine sâhip olması gerektiğini ifade etmiştir. Yine Çelik (2013)'de okul yöneticilerinin mesleğiyle ilgili alan bilgisine sâhip olmaları gerektiğini ifade etmiştir. Dolayısıyla alan bilgisine sâhip olan bir okul yöneticisi okulda sorunları çözme konusunda daha başarılı olacağı ifade edilebilir. 


\section{İlkokul Yöneticilerinin Sâhip Olması Gereken Hizmetkâr Liderli- ğin Empati Boyutuna İliş̧kin Tartışma}

Çeşitli projelerde görev almış ilkokul öğretmenlerinin görüşleri analiz edildiğinde ilkokul yöneticilerinin sâhip olması gereken hizmetkâr liderliğin empati boyutuna ilişkin özelliklerden biri ortak karar alma/işbirlikçi olmadır. Şişman (2012) eğitimde mükemmellik arayışı, etkili okullar adlı çalışmasında okul yöneticilerinin çalışanları da karar verme sürecine katıp, iş birliği içerisinde çalışılmasını belirtmiştir. Yine Çelikten (2001) tarafından yapılan "Etkili Okullarda Karar Süreci” başl1klı araştırmada acil karar gerektirmeyen durumlarda okul yöneticilerinin okullarda karar verme sürecine çalışanların da katılmasının gerekliliği vurgulanmıştır. Yöneticiler çalışanlarla ortak kararlar alıp, iş birliği yaparlarsa etkili bir okul oluşturabilirler.

Araştırmaya katılan öğretmenlerin görüşlerine göre ilkokul yöneticilerinin sâhip olması gereken hizmetkâr liderliğin empati boyutuna ilişkin özellikler arasında iyi bir dinleyici olma yer almaktadır. Helvacı (2010) tarafindan yapılan ilköğretim okul yöneticilerinin etik liderlik davranışlarını gösterme düzeyleri ile ilgili araştırmada okul yöneticilerinin iyi bir dinleyici olarak etik liderlik davranışı sergileyebileceği vurgulanmıştır. Ayrıca Taylor (2002) tarafından yapılan araştırmada ise etkili bir hizmetkâr lider olabilmek için liderin etkili bir dinleyici olması ve izleyicilerinin onları anladığını ve onlarla ilgilendiğini hissettirmesine bağlı olduğunu ifade etmiştir. Okul yöneticileri çevresindekileri dinleyerek onları önemsediğini göstermesi örgütsel amaçların gerçekleşmesi açısından son derece önemli olduğu söylenebilir.

Araştırmaya katılan öğretmenlerin görüşlerine göre ilkokul yöneticilerinin sâhip olması gereken hizmetkâr liderliğin empati boyutuna ilişkin özellikler arasında etkili iletişim becerisine sâhip olma yer almaktadır. Tutar ve Y1lmaz (2013) örgütlerde iletişimle ilgili yaptığı çalışmasında etkili iletişim kurmanın örgütsel amaçları gerçekleştirmede önemli bir araç olduğunu belirtmiştir. DeGraaff, Tilley ve Neal (2001) örgüt içerisindeki iletişim problemlerinden dolayı örgütün enerjisinin büyük bölümünün boşa harcandığ1 vurgulanmıştır. Ayrıca empatik iletişime dayalı bir anlayışın iletişim problemlerini büyük ölçüde azaltacağ 1 ifade edilmiştir. Dolayısıyla okulda güçlü bir kültür oluşturmak için okul yöneticilerinin etkili iletişim becerilerine sâhip olmaları gerektiği söylenebilir. 


\section{İlkokul Yöneticilerinin Sâhip Olması Gereken Hizmetkâr Liderli- ğin Özgecil Davranışlar Boyutuna İlişkin Tartışma}

Çeşitli projelerde görev almış ilkokul öğretmenlerinin görüşleri analiz edildiğinde ilkokul yöneticilerinin sâhip olması gereken hizmetkâr liderliğin özgecil davranışlar boyutuna ilişkin özelliklerden biri problem çözme becerisine sâhip olmadır. Şahin (2013) tarafindan yapılan araştırmada da okul yöneticilerinin örgütteki sorunları çözme yeteneğine sâhip olması gerektiğini ifade edilmiştir. Dolayısıyla okul müdürlerinin problem çözme becerisine sâhip olmasının örgütün gelişmesi ve iyileşmesi için gerekli yönetici özelliklerinden biri olduğu ifade edilebilir.

Araştırmaya katılan öğretmenlerin görüşlerine göre ilkokul yöneticilerinin sâhip olması gereken hizmetkâr liderliğin özgecil davranışlar boyutuna ilişkin özellikler arasında adanmış olma yer almaktadır. Aslan ve Yıldırım (2004) tarafindan yapılan "Okul Yöneticisinden Beklentiler" başlıklı araştırmada okul yöneticilerinin mesleğine karşı inanmış ve adanmış olması gerektiği vurgulanmıştır. Yine Çelik (2013) okul yöneticilerinin mesleklerine adanmış olması gerektiğini ifade etmiştir. Çünkü adanmış okul yöneticileri kurumları için canla başla çalıştıklarından, başarılarının yüksek olması kaçınilmazdır.

Avolio ve Locke (2002) yaptığı araştırmada özgecil davranışların örgütün işleyişini kolaylaştırdığı ve çalışanları üzerinde bağlılık, aidiyet ve adanmışlık gibi duygulara neden olduğunu belirtmiştir. Yapılan araştırmada ise hizmetkâr liderliğin özgecil davranışlar boyutuna ilişskin liderin adanmışlık, personeli sâhiplenme, inisiyatif alma gibi özelliklere sâhip olması gerektiği ifade edilmiştir. Page ve Wong (2000) tarafindan yapılan araştırmada hizmetkâr liderlikte; dürüstlük, sorumluluk, kendini adama, insana saygı gibi örgütsel davranışların önemi vurgulanmaktadır.

\section{İlkokul Yöneticilerinin Sâhip Olması Gereken Hizmetkâr Liderli- ğin Alçak Gönüllülükk Boyutuna İlişkin Tartışma}

Çeşitli projelerde görev almış ilkokul öğretmenlerinin görüşleri analiz edildiğinde ilkokul yöneticilerinin sâhip olması gereken hizmetkâr liderliğin alçak gönüllülük boyutuna ilişkin özelliklerden biri özeleştiri yapma olarak belirlenmiştir. Banoğlu ve Peker (2012) yaptıkları araştırmada öğrenen örgüt olma yolunda okul yöneticilerinin kendilerine ilişkin algılarında özeleştiri yapmaları gerektiği vurgulanmıştır. Şişman (2012) tarafından yapılan çalışmada da etkili okul yöneticilerinin eleştiriye açık olmaları ve özeleştiri ya- 
pabilmeleri gerektiğini ifade etmiştir. Dolayısıyla okul yöneticilerinin özeleştiri yapması eksikliklerini fark edip buna ilişkin önlemler alması açısından oldukça önemli olduğu söylenebilir.

İlkokul yöneticilerinin sâhip olması gereken hizmetkâr liderliğin alçak gönüllülük boyutuna ilişkin özelliklerden biri de takım çalışması/işbirlikçi olmadır. Çelikten (2001) etkili okulda karar alma ile ilgili çalışmasında okulda kararlar alınırken okul yöneticilerinin çalışanları da sürece katıp, işbirliği içerisinde olmaları gerektiğini belirtmiştir. Yine Çelik (2013) okul yöneticilerinin okul içerisinde takım ruhu oluşturmaları gerektiğini ifade etmiştir. Örgüt içerisinde verimliliğin ve paylaşımcılığın arttırılması için takım ruhu oluşturulması gerektiği ifade edilebilir.

Patterson (2003) tarafindan yapılan araştırmada ise alçak gönüllülüğün sosyal ilişkilerde içtenlik ve saygı uyandırdığ 1 belirtilmiştir. Aksi takdirde bencil tutum ve davranışların lidere karşı olumsuz duygular geliştirilmesine neden olduğu belirtilmiştir. Dolayısıyla bu çalışmada hizmetkâr liderliğin alçak gönüllülük boyutuna ilişkin sorumluluk sâhibi olma, fedakârlık ve insan ilişkilerine önem verme özellikleri, Patterson (2003) tarafından yapılan araştırmanın bulgularıyla birbirini destekler nitelikte olduğu ifade edilebilir.

\section{İlkokul Yöneticilerinin Sâhip Olması Gereken Hizmetkâr Liderli- ğin Adâlet Boyutuna İlişkin Tartışma}

Çeşitli projelerde görev almış ilkokul öğretmenlerinin görüşleri analiz edildiğinde ilkokul yöneticilerinin sâhip olması gereken hizmetkâr liderliğin adâlet boyutuna ilişkin özelliklerden biri âdil/objektif olma olarak belirlenmiştir. Gümüşeli (2001) ve Çelik (2013) taraflarından yapılan çalışmalarda okul müdürlerinin âdil olma gibi bir takım etik değerlere sâhip olmaları gerektiği vurgulanmıştır. Yine Balyer ve Gündüz (2011) değişik ülkelerde okul müdürlerinin yetiştirilmesi ile ilgili araştırmada okul müdürlerinin adil olmaları gerektiğini ifade edilmiştir. Dolayısıyla okul yöneticilerinin okuldaki objektif davranışları, çalışanların performansına olumlu katkılar sunacağı ifade edilebilir.

Araştırmaya katılan öğretmenlerin görüşlerine göre ilkokul yöneticilerinin sâhip olması gereken hizmetkâr liderliğin adâlet boyutuna ilişkin özellikler arasında iletişim kurma yer almaktadır. Özdemir (2012) eğitim örgütlerinin sağlıklı bir kültüre sâhip olmaları için iletişim kurma yeterliliğine sâhip olmaları gerektiğini ifade etmiştir. Diğer taraftan Şahin (2000) ve Özan 
(2006) taraflarından yapılan araştırmalarda da okul yöneticilerinin iletişim kurma becerisine sâhip olması gerektiği belirtilmiştir.

Konovsky ve Pugh (1994), Niehoff ve Moorman (1993), Organ (1990) yaptıkları araştırmalarda yöneticilerin âdil tutum ve davranışlarda bulunmaları izleyicilerinin içsel kabul, fedakârlık, bağlılık ve adanmışlık düzeylerini olumlu yönde etkilediği tespit edilmiştir. Bu araştırmada ise okul yöneticilerinin hizmetkâr liderliğin adâlet boyutuna ilişkin objektif olma, tarafsız olma, sözünde durma, güven verme, dürüst olma ve samimi olma özellikleri ön plana çıkmıştır.

\section{İlkokul Yöneticilerinin Sâhip Olması Gereken Hizmetkâr Liderli- ğin Dürüstlük Boyutuna İlişkin Tartışma}

Çeşitli projelerde görev almış ilkokul öğretmenlerinin görüşleri analiz edildiğinde ilkokul yöneticilerinin sâhip olması gereken hizmetkâr liderliğin dürüstlük boyutuna ilişkin özelliklerden biri güven verme olarak belirlenmiştir. Şahin (2000) tarafindan yapılan okul müdürlerinin sâhip olması gereken yeterlilikleri ile ilgili araştırmada okul yöneticilerinin güven verme özelliğine sâhip olması gerektiği vurgulanmıştır. Okul yöneticileri kurumlarında başarıyı sağlamak için kurumlarına yerleştirmesi gereken özelliklerden biri de güven vermedir. Dolayısıyla zeminine güven oturtulan bir ortamda örgütsel başarının sağlanmasının kaçınılmaz olduğu ifade edilebilir.

Araştırmaya katılan öğretmenlerin görüşlerine göre ilkokul yöneticilerinin sâhip olması gereken hizmetkâr liderliğin dürüstlük boyutuna ilişkin özellikler arasında âdil olma yer almaktadır. Aslan, Özer ve Bakır (2009) okul kültürüyle ilgili yaptıkları araştırmada katılımcılar âdil bir kurumsal işleyişi okul kültürüne yerleştirmek gerektiğini belirtmiştir. Yine Işık (2003) tarafindan yapılan okul müdürlerinin yetiştirilmesiyle ilgili araştırmada okul müdürlerinin âdil ve tutarlı bir yapıya sâhip olması gerektiği belirtilmiştir. Okul müdürlerinin kurumda âdil davranışlar sergilemesiyle çalışanların kuruma olan bağl11ıkları artacaktır. Bunun da kurumsal başarıyı arttıracağı belirtilebilir.

Cassel ve Holt (2008) yaptıkları araştırmada hizmetkâr liderlerin en önemli özelliklerinden birinin güven sağlayıcı olan dürüstlük olduğunu belirmektedirler. Ayrıca, Joseph ve Winston (2005) taraflarından yapılan araştırmada yöneticiye ilişkin hizmetkâr liderlik algılarının lidere ve örgüte güvenle pozitif yönde anlamlı ilişki içerisinde olduğu sonucuna varılmıştır. 
Benzer şekilde bu araştırmada da dürüstlük boyutunu yerine getirebilmeleri için yöneticilerin güven veren bir yapıda olmaları gerektiği dikkat çeken öğretmen görüşler arasındadır.

\section{Sonuçlar}

Araştırma bulgularından yola çıkarak bir lider olarak okul yöneticisinin sâhip olması gereken özelliklere ilişkin öğretmen görüşlerinin genel olarak 20 kategoride toplandığ1 görülmüştür. Kategoriler incelendiğinde bir lider olarak okul yöneticisinin; etkili iletişim becerisine sâhip olma, empati kurma, alan bilgisi, dürüst olma, örnek/model olma, problem çözme becerisine sâhip olma, işbirlikçi olma, disiplinli olma, hoşgörülü olma, vizyon sâhibi olma, demokratik olma, gelişime açık olma, saygılı olma, yaratıcı düşünme, alçak gönüllü olma, tutarlı olma, karakterli olma, risk alabilme ve mizah yeteneğine sâhip olma özelliklerine/yeterliliklerine sâhip olması gerektiği anlaşılmaktadır. Bu durumda bir hizmetkâr lider olarak okul yöneticilerinde bulunması gereken özelliklerden ağırlıklı olarak kişisel özelliklerine vurgu yapıldığı söylenebilir. Kişisel özelliklerin yanı sıra öğretmenler, hizmetkâr lider olarak okul müdürlerinin meslekî bilgi ve becerilere de sâhip olması gerekliliği üzerinde durmaktadırlar.

Öğretmenlerin görüşlerine göre, ilkokul yöneticilerinin hizmetkâr lider olabilmesi için gerekli empati yeteneği 16 alt özellikten oluşmaktadır. Bunlar; ortak karar alma/işbirlikçi olma, iyi bir dinleyici olma, etkili iletişim becerisine sâhip olma, anlayışlı olma, açık ve net olma, paylaşımcı olma, saygılı olma, mesafeli olma (iletişimde duracağı yeri bilme anlamında), samimi olma, çözüm bulma/ yol gösterme, dürüstlük, âdil olma, güven verme, ön yargısız olma, alçakgönüllü olma ve mizah yeteneğine sâhip olmadır. Buradan hareketle belirtilen özelliklere sâhip olan okul yöneticilerinin empati kurma konusunda sorun yaşamayacağ 1 düşünülmektedir. Dolayısıyla empati yeteneği yüksek yönetici, hizmetkâr lider olarak yetki gücünün yanında etki gücünü de kullanabilecektir. Bu durum MEB gibi aşırı merkezî yapıların doğal bir sonucu olarak ortaya çıkan biçimsel güç kullanımına dayalı --güç mesafesinin yüksek olduğu-- örgüt kültürünün, kişisel güç kaynaklarını da etkili kullanabilen daha sağlıklı kültüre dönüşümüne kaynaklık edebilir.

Öğretmenlerin, ilkokul yöneticilerinin sâhip olması gereken hizmetkâr liderliğin özgecil davranışlar boyutuna ilişkin görüşleri 18 kategoride toplanmıştır. Bu kategoriler sonucunda hizmetkâr liderliğin özgecil davranışlar boyutuyla ilgili okul yöneticisinin; problem çözme becerisine sâhip olma, 
adanmışlık, istekleri karşılama, fikir alışverişinde bulunma, ihtiyaçları giderme, iyi model olma, sakinlik, yönlendirme, inisiyatif alma, yeterli bilgi ve beceriye sâhip olma, önlem alma, âdil davranma, dürüstlük, farklı bakış açısına sâhip olma, teşvik etme, ödüllendirme, personeli sâhiplenme ve empati kurması gerektiği ortaya çıkmıştır. Bulgulardan yola çıkılarak hizmetkâr lider olarak okul yöneticisinin kurumda birtakım davranışlar sergilemesi gerektiğine vurgu yapılmıştır. Bu davranışların daha çok liderin kişisel özellikleri ile ilgili olduğu görülmektedir.

Öğretmenlerin, ilkokul yöneticilerinin sâhip olması gereken hizmetkâr liderliğin alçak gönüllülük boyutuna ilişkin görüşleri 9 kategoride toplanmıştır. Bu kategoriler sonucunda hizmetkâr liderliğin alçak gönüllülük boyutuyla ilgili okul yöneticisinin; özeleştiri yapma, takım çalışması/işbirlikçi olma, statüye önem vermeme, sorumluluk sâhibi olma, motive etme/ödüllendirme, başkalarını düşünen/fedakâr, insan ilişkilerine önem verme, karakter sâhibi olma ve yol gösterici/rehber olmaları gerektiği ortaya çıkmıştır. Bulgulardan yola çıkarak hizmetkâr liderin okulda alçak gönüllü olmaları için birtakım özelliklere sâhip olması ve ona göre davranması gerektiği belirtilmiştir. Bu özelliklerin daha çok liderin kişiliğine yönelik özellikler olduğu görülmektedir.

Öğretmenlerin, ilkokul yöneticilerinin sâhip olması gereken hizmetkâr liderliğin adâlet boyutuna ilişkin görüşleri 9 kategoride toplanmıştır. $\mathrm{Bu}$ kategoriler sonucunda hizmetkâr liderliğin adâlet boyutuyla ilgili okul yöneticisinin; âdil/objektif olma, eşit olma, iletişim kurma, sözünde durma, tutar11/istikrarlı olma, güven verme, empati kurma, dürüst olma ve samimi olmas1 gerektiği ortaya çıkmıştır. Bulgulardan yola çıkarak katılımcılar okul yöneticilerinin hizmetkâr bir lider olarak kurum içerisinde adâletli olmaları için birtakım davranışlar sergilemesi gerektiği belirtmişlerdir. Bu özellikleri sergileyen hizmetkâr liderlerin okulda adâleti sağlayabileceği düşünülmektedir. Okulda adil davranışlar sergileyen okul müdürlerinin, öğretmenlerinde okula karş1 olumlu duygular geliştirmesi beklenmektedir.

Öğretmenlerin, ilkokul yöneticilerinin sâhip olması gereken hizmetkâr liderliğin dürüstlük boyutuna ilişkin görüşleri 18 kategoride toplanmıştır. $\mathrm{Bu}$ kategoriler sonucunda hizmetkâr liderliğin dürüstlük boyutuyla ilgili okul yöneticisinin; güven verme, âdil olma, kişilik özelliklerine uygun görev dağlımı yapma, tutarlı olma, fikir alışverişi/iletişim kurma, ödüllendirme, doğruluk/doğru söyleme, sözünde durma, görünür olma, samimi/iyimser 
olma, açık sözlü olma, destek olma, fedakâr, ölçüte göre değerlendirme yapma, tarafsız olma, ön yargısız olma, işbirlikçi olma ve alçak gönüllü olması gerektiği ortaya çıkmıştır. Belirtilen bulgulardan yola çıkarak bu özellikleri taşıyan hizmetkâr liderler öğretmenler tarafından dürüst olarak nitelendirilecektir. Yöneticilerinin dürüst olduğunu gören öğretmenler liderlerine daha çok güvenebilecekler ve okullarına olan bağlılıkları artabilecektir.

Öğretmenler, hizmetkâr bir lider olarak okul yöneticilerinden oldukça fazla özellik beklemektedir. Bu nedenle okul yöneticilerinin hizmetkâr liderlikle ilgili farkındalık düzeyini arttırmaya yönelik hizmet içi eğitim, kurs, seminer vb. şekillerde liderlik eğitimi almalarına olanak sağlanabilir. Hizmetkar liderliğe ilişkin öğretmenler tarafından yüklenen anlamın genellikle kişisel özellikler olduğu gerçeğinden hareketle, yöneticiliğe atama sürecinde kişisel özellikleri belirleyebilecek psikometrik testlerin kullanılması ve değerlendirmede dikkate alınması gerektiği söylenebilir. Hizmetkar liderliğin göreceli yeni bir yaklaşımı yansıtması ve kültürel olarak toplumcu bir anlayışa sahip Türkiye için uygunluğu nedenleriyle daha fazla araştırmaya konu edilmesi gerektiği vurgulanabilir. Ayrıca bu araştırmada öğretmen görüşlerine yer verilmiştir. Diğer okul paydaşlarının da görüşleri alınarak karşılaştırmalı araştırmalar yapılabilir.

\section{Kaynakça}

Açıkalın, A. ve Turan, S. (2011). Bir anlam köprüsü inşa etme aracı olarak okullarda etkili iletişim. Ankara: Önder Matbaacıllk.

Akdöl, B. (2015). Hizmetkâr liderlik. İstanbul: Derin Yayınları.

Akyüz, B. (2012). Hizmetkâr liderlik davranışlarının örgütsel adâlet, örgütsel vatandaşlıkdavranışları ve performans üzerine etkisi: Ĕgitim sektörü üzerine bir araştırma. Yayınlanmamış doktora tezi, Gebze Yüksek Teknoloji Enstitüsü Sosyal Bilimler Enstitüsü.

Akyüz, B. (2014). Yönetimde hizmetkâr liderlik. Ankara: Gece Kitaplı̆̆ 1 Yayınevi.

Argon, T. (2004). İlköğretim kurumlarındaki yöneticilerin liderlik ve yöneticilik özelliklerine ilişkin görüşleri. Abant İzzet Baysal Üniversitesi Ĕ̈itim Fakültesi Dergisi, 4(7), 81-98.

Aslan B. ve Yıldırım N. (2004, Temmuz). Okul yöneticisinden beklentiler. XIII. Ulusal Eğitim Bilimleri Kurultayı, İnönü Üniversitesi Eğitim 
Fakültesi, Malatya.

Aslan, M., Özer, N. ve Bakır, A. A. (2009). Okul kültürüne ilişkin yönetici ve öğretmen görüşleri: Nitel bir araştırma. Ilköğretim Online, 8(1), 268-281.

Aslan, Ş. ve Özata, M. (2011). Sağlık çalışanlarında hizmetkâr liderlik: Dennis-Winston ve Dennis-Bocernea hizmetkâr liderlik ölçeklerinin geçerlik ve güvenirlik araştırması. Celal Bayar Üniversitesi İktisadi ve İdari Bilimler Dergisi, 18(1), 139-154.

Avolio, B. J. ve Locke, E. E. (2002). Philosophies of leader motivation: Altruism versus egoism. Leadership Quarterly, 13(2), 169-191.

Bakan, İ. ve Büyükbeşe, T. (2010). Liderlik "türleri" ve "güç kaynakları"na ilişkin mevcut-gelecek durum karşılaştırması: Eğitim kurumu yöneticilerinin algılarına dayalı bir alan araştırması. Karamanoğlu Mehmetbey Üniversitesi Sosyal ve Ekonomik Araştırmalar Dergisi, 12(19), 73-84.

Bakan, İ. ve Doğan, F. İ. (2012). Hizmetkâr liderlik. Kahramanmaraş Sütçü İmam Üniversitesi İktisadi ve İdari Bilimler Fakültesi Dergisi, 2(2), $1-12$.

Balay R., Kaya, A. ve Yılmaz, R. (2014). Eğitim yöneticilerinin hizmetkâr liderlik yeterlilikleri ile farklılıkları yönetme becerileri arasındaki ilişki. Eğitim Bilimleri ve Araştırmaları Dergisi, 4(1), 230-248.

Balyer, A. ve Gündüz, Y. (2011). Değişik ülkelerde okul müdürlerinin yetiştirilmesi: Türk eğitim sistemi için bir model önerisi. Kuramsal Eğitim Bilim, 4(2), 182-197.

Balyer, A. ve Gündüz, Y. (2013). Öğretim lideri olarak okul müdürlerinin öğrencilerin akademik başarısı üzerindeki etkisinin incelenmesi. Ballkesir Üniversitesi Sosyal Bilimler Enstitüsü Dergisi, 16(29), 107-128.

Banoğlu, K. ve Peker, S. (2012). Öğrenen örgüt olma yolunda ilköğretim okul yöneticilerinin okullarına ve kendilerine ilişkin algı durumları. Hacettepe Üniversitesi Eğitim Fakültesi Dergisi, 43, 71-82.

Baytok, A. ve Ergen, F. D. (2013). Hizmetkâr liderliğin örgütsel vatandaşlık davranışına etkisi: İstanbul ve Afyonkarahisar'daki beş yıldızlı otel işletmelerinde bir araştırma. İşletme Araştırmaları Dergisi, 5(4), 
105-132.

Bell, J. (1999). Doing your research project. Buckingham, USA: Open University Press.

Büyüktatl1, M. (2015). Okul yöneticilerinin duygusal zeka düzeyleriyle hizmetkâr liderlik davranışları arasındaki ilişki. Yayınlanmamış yüksek lisans tezi, Mevlana Üniversitesi Sosyal Bilimler Enstitüsü.

Can, N. (2010). Öğretmen liderliğinde müdürlerin etkisi. Dumlupınar Üniversitesi Sosyal Bilimler Dergisi, 27, 57-66.

Cassel, J. ve Holt, T. (2008). The servant leader-mature and thoughtful board members work for the common good-not for individual gain. American School Board Journal, 195, 34-35.

Cerit, Y. (2007). İlköğretim okulu müdürlerinin hizmet yönelimli liderlik rollerini gerçekleştirme düzeyleri. Hacettepe Üniversitesi Eğitim Fakültesi Dergisi, 33, 88-98.

Cerit, Y. (2008). İlköğretim okulu müdürlerinin hizmet yönelimli liderlik davranışlarının öğretmenlerin tükenmişliklerine etkisi. Kuram ve $U y$ gulamada Eğitim Yönetimi Dergisi, 55, 547-570.

Cerit, Y. (2009). The effects of servant leadership behaviours of school principals on teachers' job satisfaction. Educational Management Administration Leadership, 37(5), 600-623.

Coşkunlar, E. (2011). Belediyelerde yöneticilerin hizmetkâr liderlik rollerine ilişkin personel görüşleri (Eskişehir ili örneği). Yayınlanmamış yüksek lisans tezi, Eskişehir Osmangazi Üniversitesi Sosyal Bilimler Enstitüsü.

Çelik, V. (2013). Eğitimsel liderlik. Ankara: Pegem A Yayıncılık.

Çelikten, M. (2001). Etkili okullarda karar süreci. Erciyes Üniversitesi Sosyal Bilimler Enstitüsü Dergisi, 1(11), 1-12.

Çetin, H. (2014). Otel işletmelerinde hizmetkâr liderliğin çalışanların iş tatmini ve işten ayrlma niyeti üzerine etkisi. Yayınlanmamış doktora tezi, Nevşehir Üniversitesi Sosyal Bilimler Üniversitesi.

Çiçek, O. (2015). Eğitim örgütlerinde hizmetkâr liderliğe yönelik bir araştırma. Yayınlanmamış yüksek lisans tezi, Eskişehir Osmangazi Üni- 
versitesi Eğitim Bilimleri Enstitüsü.

Dal, L. (2014). Hizmetkâr liderlik ile lider-üye etkileşimi arasındaki ilişki: Bir devlet üniversitesinde araştırma. Yayınlanmamış yüksek lisans tezi, Eskişehir Osmangazi Üniversitesi Sosyal Bilimler Enstitüsü.

Dal, L. ve Çorbacıoğlu, S. (2014). Hizmetkâr liderlik davranışları ve lider-üye etkileşimi ilişkisi: Bir devlet üniversitesi üzerine araştırma. Süleyman Demirel Üniversitesi İktisadi ve İdari Bilimler Fakültesi Dergisi, 19(4), 287-310.

DeGraaf, D. G., Tilley, C. ve Neal, L. L. (2001). Servant-leadership characteristics in organizational life. Voices of Servant-Leadership Series, Booklet 6. Indianapolis: Greenleaf Center for Servant-Leadership.

Dinçer, M. K. ve Bitirim, S. (2007). Kurum kültürü çalışmalarında hizmetkâr liderlik anlayışı ile değer yaratmak. İstanbul Üniversitesi İletişim Fakültesi Dergisi, 28, 61-72.

Duyan, E. C. (2012). Hizmetkâr liderlik: Çalışan iyilik hali ve çalışma yaşamının kalitesi ile ilişkileri üzerine bir araştırma. Yayınlanmamış doktora tezi, Uludağ Üniversitesi Sosyal Bilimler Enstitüsü.

Duyan, C. ve Dierendonck, D. V. (2014). Hizmetkâr liderliği anlamak: Teoriden ampirik araştırmaya doğru. Sosyoloji Konferanslart Dergisi, 49(1), 1-32.

Ekinci, A. (2015). Okul müdürlerinin hizmetkâr liderlik davranışları ölçeğinin geliştirilmesi ve hizmetkâr liderlik davranışlarının öğretmen görüşlerine göre değerlendirilmesi. Ĕgitim ve Bilim Dergisi, 40(179), 341-360.

Ergen, F. D. (2013). Hizmetkâr liderliğin örgütsel vatandaşlık davranışına etkisi: Istanbul ve Afyonkarahisar'daki beş yıldızlı otel işletmelerinde bir araştırma. Yayınlanmamış yüksek lisans tezi, Afyon Kocatepe Üniversitesi Sosyal Bilimler Enstitüsü.

Find1kçı, İ. (2013). Bir gönül yolculuğu hizmetkâr liderlik. Ankara: Alfa Yayınc1lik.

Greenleaf, R. K. (1977). The servant as leader. New York: Paulist Press.

Greenleaf, R. K. (1998). The servant as leader. New York: Paulist Press.

Güler, A., Halıcıoğlu, M. B. ve Taşğın, S. (2013). Sosyal bilimlerde nitel 
araştırma yöntemleri. Ankara: Seçkin Yayıncılık.

Gümüşeli, A. İ. (2001). Çağdaş okul müdürünün liderlik alanları. Kuram ve Uygulamada Ë̆itim Yönetimi Dergisi, 21, 531-548.

Helvacı, M. A. (2010). İlköğretim okulu yöneticilerinin etik liderlik davranışı gösterme düzeyleri. Zeitschrift Für Die Welt Der Türken/Journal Of World Of Turks, 2(1), 391-410.

Işık, H. (2003). Okul müdürlerinin yetiştirilmelerinde yeni bir model önerisi. Hacettepe Üniversitesi Ĕ̈itim Fakültesi Dergisi, 24, 206-211.

Işıkoğlu, N. (2005). Eğitimde nitel araştırma. Eğitim Araştırmaları Dergisi, 20(5), 158-165.

Joseph, E. E. ve Winston, B. E. (2005). A correlation of servant leadership, leader trust, and organizational trust. Leadership \& Organization Development Journal, 26(1), 6-22.

Kahveci, H. (2012). İlköğretim okullarında hizmetkâr örgüt liderliğinin incelenmesi. Yayınlanmamış yüksek lisans tezi, Eskişehir Osmangazi Üniversitesi Eğitim Bilimleri Enstitüsü.

Kırmızı, İ. (2014). Sivil toplum kuruluşlarında hizmetkâr liderliğin rolü: Kütahya ili örneği. Yayınlanmamış yüksek lisans tezi, Dumlupınar Üniversitesi Sosyal Bilimler Enstitüsü.

Konovsky, M. A. ve Pugh, D. S. (1994). Citizenship behavior and social exchange. Academy of Management Journal, 37(3), 656-669.

Kumbetoğlu, B. (2005). Sosyolojide ve antropolojide niteliksel yöntem ve araştırma. İstanbul: Bağlam Yayınları.

Lincoln, Y. S. ve Guba, E. G. (1985). Naturalistic inquiry. Beverly Hills, Ca: Sage.

Merriam, S. B. (2013). Nitel araştırma desen ve uygulama için bir rehber. (S. Turan, Çev.). Ankara: Nobel Yayınları. (Orijinal çalışma basım tarihi 2009)

Niehoff, B. P. ve Moorman, R. H. (1993). Justice as a mediator of the relationship between methods of monitoring and organizational citizenship behavior. Academy Of Management Journal, 36(3), 527-556.

Okçu, V. (2011). Türkiye’de okul yöneticilerinin yetiştirilmesi ve atanmasına 
ilişkin mevcut durum, beklentiler ve öneriler. Elektronik Sosyal Bilimler Dergisi, 10(37), 244-266.

Organ, D. W. (1990). The motivational basis of organizational citizenship behavior. Research in Organizational Behavior, 12, 43-72.

Öner, Z. H. (2008). Hizmetkâr yöneticilik ile işe kapılma değişkenleri arasındaki ilişkide, örgütsel adâletin ara değişken olarak etkisi; Tutarlılık anlayışı ve işin karmaşıklık düzeyinin şartlı değiş̧en olarak rolleri. Yayınlanmamış doktora tezi, Marmara Üniversitesi Sosyal Bilimler Enstitüsü.

Özan, M. B. (2006). İlköğretim okulu yöneticilerinin iletişim becerilerinin öğretmen ve yönetici bakış açısıyla değerlendirilmesi. Eurasian Journal of Educational Research (EJER), 24(8), 153-160.

Özdemir, S. (2012). İlköğretim okullarında okul kültürü ile örgütsel sağl1k arasındaki ilişki. Kuram ve Uygulamada Eğitim Yönetimi, 18(4), 599-620.

Özdemir, S. ve Sezgin, F. (2002). Etkili okullar ve öğretim liderliği. Sosyal Bilimler Dergisi, 2(3), 266-282.

Özkan, M. (2016). Liderlik hangi sıfatları, nasıl alıyor? Liderlik konulu makalelerin incelenmesi. Gaziantep University Journal of Social Sciences, 15(2), 615-639.

Özmutlu, İ. (2011). Bedensel engelli sporcularda antrenörlerin hizmetkâr liderlik davranışlarının sporcu tatmini ile ilişkisi. Yayınlanmamış doktora tezi, Gazi Üniversitesi Sağlık Bilimleri Enstitüsü.

Page, D. ve Wong, T. P. (2000). A conceptual framework for measuring servantleadership. S. Adjibolosoo, (Ed.), The human factor in shaping the course of history and development. Lanham: University Press of America.

Patterson, K. A. (2003). Servant leadership: A theoretical model. Virginia Beach, VA: Regent University School of Leadership Studies.

Polat, F. (2013). Eğitim denetmenlerinin ve ilköğretim okul müdürlerinin sergiledikleri hizmetkâr liderlik düzeyi (Elazığ ili örneği). Yayınlanmamış yüksek lisans tezi, Fırat Üniversitesi Eğitim Bilimleri Enstitüsü.

Sanı, F. O., Atan, Ö., Çalışkan, S. C. ve Yozgat, U. (2013). Öğretim üyelerinin 
hizmetkâr liderlik davranışları ve ardılları üzerine bir araştırma. Ege Akademik Bakış Dergisi, 13(1), 63-82.

Sincar, M. (2015). Teknoloji liderliği. N. Konan, (Ed.), Eğitim yönetiminde yeni liderlik yaklaşımları Cilt-1 içinde (21-41). Ankara: Pegem Akademi Yayınları.

Şişman, M. (2012). Eğitimde mükemmellik arayışı etkili okullar. Ankara: Pegem A Yayınc1lık.

Şahin, A. E. (2000). İlköğretim okul müdürlerinin yeterlilikleri. Kuram ve Uygulamada Eğitim Yönetimi Dergisi, 6(2), 243-260.

Şahin, S. (2013). İlköğretim okulu müdürlerinin yönetsel etkililik düzeyine ilişsin ögretmen görüşleri (İzmit ilçesi örneği). Yayınlanmamış yüksek lisans tezi, Hacettepe Üniversitesi Sosyal Bilimler Enstitüsü.

Şimşek, Y. ve Altınkurt, Y. (2009). Endüstri meslek liselerinde görev yapan öğretmenlerin okul müdürlerinin iletişim becerilerine ilişkin görüşleri. Akademik Bakıs, 17, 1-16.

Şişman, M. (2012). Eğitimde mükemmellik araylşı etkili okullar. Ankara: Pegem A Yayıncilık.

Taha, F. ve Gedikoğlu, T. (2009). İlköğretim okulu müdürlerinin liderlik rolleri. Kuram ve Uygulamada Eğitim Yönetimi, 58, 274-298.

Taylor, T. A. (2002). Examination of leadership practices of principals identified as servant leaders. Dissertation Abstracts International, 63(5), 1661. Umi No. 3052221.

Tutar, H. ve Y1lmaz, M. K. (2013). Genel ve örgütsel boyutuyla iletişim. Ankara: Seçkin Yayıncılık.

Uzun, A. (2015). Otel işletmelerinde hizmetkâr liderliğin tükenmişlik üzerindeki etkisi. Yayınlanmamış yüksek lisans tezi, Nevşehir Hacı Bektaş Veli Üniversitesi Sosyal Bilimler Enstitüsü.

Üstün, A. ve Bozkurt, E. (2005). İlköğretim okulu müdürlerinin kendilerini algılayışlarına göre problem çözme becerilerini etkileyen bazı mesleki faktörlere ilişkin algılar. Kastamonu Eğitim Dergisi, 11(1), 28-46.

Yıldırım, A ve Şimşek, H. (2013). Sosyal bilimlerde nitel araştırma yöntemleri. Ankara: Seçkin Yayıncılık. 
Yılmaz, C. (2013). Hizmetkâr liderlik ile örgütsel bağlllık arasındaki ilişki. Yayınlanmamış yüksek lisans tezi, Gebze Yüksek Teknoloji Enstitüsü Sosyal Bilimler Enstitüsü. 